\title{
Development of cost-effective enclosing structures with high heat transfer resistance
}

\author{
Alexandr Meneiliuk ${ }^{1 *}$, Stanislav Kyryliuk ${ }^{1}$, and Larisa Cherepashchuk ${ }^{2}$ \\ ${ }^{1}$ Odessa State Academy of Civil Engineering and Architecture, 65029, Odessa, Ukraine \\ ${ }^{2}$ Chernomor NIIproekt, 65029, Odessa, Ukraine
}

\begin{abstract}
Considered is the solution to the problem of choosing an economical option for the construction of low-rise buildings and the creation of new economical design solutions with high thermal performance. The well-known technologies of building construction are analyzed using qualitative, quantitative and comparative analysis. Quantitative indicators were selected, such as wall thickness, weight of 1 $\mathrm{m} 2$ of wall, resistance to heat transfer, area of premises, cost, durability, tendency to shrinkage. As qualitative indicators used: seasonality of the use of solutions, resistance to the formation of mold, decay and destruction, especially the delivery of building materials. The method of multi-criteria analysis was also applied to determine the most effective technology. Calculated the cost of various types of design solutions based on economic calculated simulations. The technological solutions were assessed by quantitative criteria on a ten-point scale, where the minimum and maximum values were assigned points 1 and 10, respectively. Graphic modeling of the compared construction options was carried out and the corresponding diagrams were built. Added "weight" coefficient of criteria for the final decision on the choice of the optimal technology for the construction of buildings. The most effective constructive solution was selected based on the results of a comparative analysis, taking into account the "weight" coefficient.
\end{abstract}

\section{Introduction}

Today "budget" private houses occupy the second line in the rating of housing after "smart apartments". The growing popularity of individual houses is primarily due to the competitive price and tangible advantages of such a purchase compared to apartments [1]. Over the past decade, fundamental changes have taken place in the field of thermal protection of buildings. With the update of regulatory documents on thermal insulation of buildings, the map of temperature zones of Ukraine has changed in terms of reducing these zones from 4 to 2 . Thus, increasing the indicators of the minimum allowable value of heat transfer resistance. It became necessary to find new economical technologies for the construction of low-rise buildings with high thermal performance. Solving the problem of choosing an economical option for the construction of low-rise buildings will help to

\footnotetext{
${ }^{*}$ Corresponding author: meneilyk@gmail.com
} 
"saturate" the housing market with the presence of "budget" cottages with high thermal performance.

\section{Materials and methods}

The study uses a systematic approach to the analysis, generalization and classification of known building construction technologies. Methods of qualitative, quantitative and comparative analysis, including the use of the method of multi-criteria analysis, made it possible to determine the most effective technology. With the help of an experimentaltheoretical method, construction processes and patterns of changes in the main indicators of their effectiveness are described [7]. The prices of various types are calculated on the basis of economic modeling in the AVK software package [8]. For graphical modeling of the compared options, the Microsoft Excel table and chart tool was used.

\section{Results}

A large number of works have been devoted to researchers of buildings structural elements, including building elements. The authors would like to highlight the following ones «The Method of Calculating the Bearing Capacity of Compressed Stone Pillars» and «Operation of Damager H-Shaped Columns» [2,3]

For comparison, 18 structural and technological solutions for the construction of enclosing structures were selected, namely, walls made of the following materials:

1. Ceramic brick;

2. Porous ceramic blocks;

3. Shell limestone stones;

4. Aerated concrete blocks;

5. Rounded logs;

6. Glued laminated timber

7. Movable fixed formwork of "TISE" type;

8. SIP-panels;

9. Fixed formwork of "Termodom, Legodom, Izodom" type;

10. Fixed formwork of "TECHNOBLOK" type;

11. Fixed formwork of "Plastbau" type;

12. Reinforced 3-D panels (SOTA)

13. Polystyrene concrete blocks;

14. Cement particle boards;

15. Technology according to patent UA No. 115636 "Multilayer wall panel"

16. Technology under the patent UA No. 115637 "Multilayer enclosing wall structure"

17. Technologies under the patent UA No. 123124 "Multilayer wall panel"

18. Technologies under the patent UA No. 123125 "Multilayer wall"

To make the best decision on the choice of building technology, it is first important to determine which performance characteristics are most important. They can be economic, technical, environmental, social, or others. The main thing is that the chosen solutions clearly meet the task at hand.

The system of multicriteria analysis used for evaluating construction solutions allows one to characterize not only qualitative, but also quantitative parameters. A distinctive feature of multicriteria analysis is the presence of several groups of criteria, each of which allows you to describe in sufficient detail a specific construction technology, analyzing information sources, or performing the appropriate calculations.

The following most significant evaluation criteria were selected: 
quantitative:

- wall thickness - calculated based on the thickness of all layers of the finished structure, $\mathrm{mm}$;

- weight of $1 \mathrm{~m} 2$ of wall - calculated based on the weight of all layers of the finished structure, $\mathrm{kg}$

- resistance to heat transfer - calculated on the basis of the requirements of regulatory documents, $\mathrm{m} 2 \cdot \mathrm{C} / \mathrm{W}$;

- area of premises with external dimensions of buildings $10 \times 10 \mathrm{~m}$ - was calculated based on the thickness of the enclosing structure, $\mathrm{m} 2$;

- cost - calculated on the basis of a constructive solution in the software package "Automated production of estimates" (for Ukraine) UAH/m 2,

- durability - adopted on the basis of regulatory documents and literary sources, years;

- tendency to shrinkage - adopted on the basis of regulatory documents and literature sources, $\%$.

Qualitative:

- seasonality of using solutions;

- resistance to mold formation, decay and destruction;

- features of the delivery of building materials[9].

Based on information from information sources and performed calculations of resistance to heat transfer, developed estimate calculations of the cost of $1 \mathrm{~m}^{2}$ of erection of enclosing structures, a table was compiled for comparing various solutions according to the selected criteria. The quantitative assessment of the criteria was transferred from full-scale measurements to a conditional point scale. The technologies were assessed by quantitative criteria on a ten-point scale, where the minimum and maximum values were assigned points of 1 and 10, respectively. The rest of the scores are calculated using interpolation.

The solution of the patent UA No. 115636 "Multilayer wall panel", contains a fixed formwork made of extruded polystyrene foam 1, an internal load-bearing reinforced concrete layer and a reinforcing frame, anchor outlets from the foundation for fixing the expanded polystyrene.

Two parallel polystyrene foam slabs are connected by means of $\mathrm{z}$-shaped rods. The rods, in turn, are connected to the reinforcement cage of the supporting reinforced concrete layer and the reinforcing mesh installed outside the expanded polystyrene. This shape of the rods makes it easier to connect the reinforcing mesh located on the surface of the polystyrene foam boards. As well as additional stability during the installation of permanent formwork. The formwork has a facing in the form of a layer of shotcrete on a reinforcing $\operatorname{mesh}[4]$.

The rest of the technologies and other promising areas of construction and reconstruction are presented in the book "Innovations in construction and reconstruction" [5].

The tool for processing the assessments of multi-criteria analysis is the "consolidated diagram" implemented in Microsoft Excel. These diagrams are formed together with a "summary table" (Table 1), with the help of which, you can summarize, analyze, study and generalize data from external sources.

Concrete formwork blocks "TISE" (Technology of individual construction and ecology) are made directly in the wall at the place of masonry without underfloor mortar (it is enough to moisten the bottom row of blocks with water) in a specially patented "TISE" module, made of steel and designed to form one block with a cavitation of about $45 \%$. The manufacturing temperature of the formwork block is not lower than $15^{\circ} \mathrm{C}$. As a solution for the manufacture of blocks, a rigid mixture is used - sand concrete. The composition of the concrete mixture for pouring into the module is taken: cement M400, large or medium sand and water in a ratio of 1:3:0.5. The mixture is laid in the block module layer by layer, while the formwork does not need any lubrication. The mixture is compacted immediately in the 
block by a manual lubrication. The forming time of the formwork block is 5-15 minutes; after that it is stripped.

The technology of erection of monolithic structures using non-removable formwork made of cement-particle boards is based on the use of mineralized chip-cement boards. In 1956, the "VELOX" permanent formwork system was developed and patented. The basic element of the system is a slab of bark-free non-commercial hardwood and softwood $(85 \%$ of the volume), which is processed into chips, cement, liquid glass and water. Expanded polystyrene is used as a heater for fixed formwork, which is mounted with an outer plate.

The formwork consists of blocks of polystyrene concrete, which are laid on glue or dry ("SIMPROLIT", "TEPLOLIT"), and connected by reinforcement in the vertical and horizontal directions, followed by filling the voids with concrete. Polystyrene concrete blocks perform the functions of formwork and insulation. In the "MARKO" system for fixing blocks before concreting the walls, a special heat-insulating dry masonry mixture has been developed from foamed polystyrene balls, cement, special modifying additives to accelerate the setting. After mixing the composition with water and stirring, the heatinsulating masonry mortar "MARCO-KR" is obtained from the mixture.

The technology of using large-sized expanded polystyrene elements appeared in the seventies in Italy and was called Plastbau. The load-bearing structures represent a monolithic spatial system of reinforced concrete longitudinal and transverse walls, ceilings, with the use of fixed formwork, which, during operation, plays the role of an effective insulation.

Armopanel is known in the world under different names: 3DPanel, SCIP, M2-panel, Wpanel, TRIDIPANEL, ARBON panels. Monolithic construction technology using a threelayer reinforced panel, "3D Panel", was developed in the 1970s in the United States. Later, the basic design of the panel was repeated by the Austrian company E.V.G. RAABA and Italian EMMEDUO M2. Currently, the most common manufacturers of armopanels are Moneta Monolit (Italy), EVG (Austria), Armstrong (USA). In Russia there are companies "EVG - Russian Wall" (since 2003), and "Moneta Monolit" (since 2008). In Ukraine, the owner of the author's patent for the use of a similar three-layer reinforced polystyrene foam panel is the research and production association "SOTA ${ }^{\mathrm{TM}}$ ". In our country, this technology is not yet widespread, but it is a promising direction.

The formwork system received the name "TECHNOBLOCK" and consists of easily assembled formwork blocks-modules. Each module is assembled directly on the erected wall from the facade and internal facing plates using jumpers. A plate of insulation of the required thickness (expanded polystyrene or mineral wool plate) is inserted inside the module and reinforcement is installed. The modules are mounted in rows along the perimeter of the walls using a seamless masonry method (without mortar and sealant), while the facing plates of the higher rows of modules rest on the perfectly flat edges of the facing plates of the lower rows. The formwork blocks are fastened with plastic and wire ties into a single formwork structure. In the resulting space between the walls of the formwork, metal reinforcement, embedded elements can be installed in order to subsequently avoid gutting by a contour for laying communications and punching holes and openings for the entire thickness of the wall. Then concrete is placed in the formwork, separately in each row of the formwork. As a result, a load-bearing monolithic insulated and immediately lined wall is formed on the outside, and, if necessary, inside.

For the first time, frame-panel technology made it possible to build structures from multi-layer "sandwich" panels. The technology was widely used after the creation of the Sip-panel - Structural Insulated Panels in the 80s of the XX century. Today, SIP panels are $90 \%$ made in the factory together with interior and exterior decoration. House installation takes place by assembling from standard panels. The panels are attached to each other using 
joining elements made of wooden beams or boards. When using Canadian technology, the interior and exterior of the building can be varied [8].

Table 1.Comparison of selected technologies for the construction of enclosing constructions of buildings and structures

\begin{tabular}{|c|c|c|c|c|c|c|c|c|c|c|c|}
\hline $\begin{array}{l}\mathrm{N} \\
\mathrm{o} .\end{array}$ & \begin{tabular}{|l|}
$\begin{array}{l}\text { Evalu } \\
\text { ation } \\
\text { criteri } \\
\text { a }\end{array}$ \\
\\
\\
Const \\
ructiy \\
e \\
decisi \\
on \\
\end{tabular} & $\begin{array}{c}\text { Wall } \\
\text { thick } \\
\text { ness, } \\
\mathrm{mm} / \mathrm{i} \\
\mathrm{n} \\
\text { point } \\
\mathrm{s}\end{array}$ & $\begin{array}{c}\text { Resist } \\
\text { ance } \\
\text { to } \\
\text { heat } \\
\text { transf } \\
\mathrm{er}, \mathrm{m}^{2} \\
* \\
\mathrm{C} / \mathrm{W} / \\
\text { in } \\
\text { points }\end{array}$ & $\begin{array}{c}\text { Weigh } \\
\mathrm{t} \text { of } \\
1 \mathrm{~m}^{2} \text { of } \\
\text { wall, } \\
\mathrm{kg} / \text { in } \\
\text { points }\end{array}$ & $\begin{array}{c}\text { Area of } \\
\text { premises } \\
\text { with } \\
\text { external } \\
\text { dimension } \\
\text { s of } \\
\text { buildings } \\
10 \times 10 \mathrm{~m} / \\
\text { in points }\end{array}$ & $\begin{array}{l}\text { Cost, } \\
\text { UAH / } \\
\mathrm{m}^{2} / \text { in } \\
\text { points }\end{array}$ & $\begin{array}{l}\text { Durability, } \\
\text { years / in } \\
\text { points }\end{array}$ & $\begin{array}{c}\text { Shrin } \\
\text { kage } \\
\text { of the } \\
\text { wall } \\
\text { materi } \\
\text { al, } \% / \\
\mathrm{mm} / \mathrm{m}\end{array}$ & $\begin{array}{c}\text { Season } \\
\text { ality of } \\
\text { constru } \\
\text { ction, } \\
\text { time of } \\
\text { year }\end{array}$ & $\begin{array}{c}\text { Resista } \\
\text { nce to } \\
\text { moistur } \\
\text { e and } \\
\text { destruct } \\
\text { ion }\end{array}$ & $\begin{array}{c}\text { Deli } \\
\text { very } \\
\text { of } \\
\text { buil } \\
\text { ding } \\
\text { mat } \\
\text { erial } \\
\text { s }\end{array}$ \\
\hline 1 & 2 & 3 & 4 & 5 & 6 & 7 & 9 & & 10 & 11 & 12 \\
\hline 1 & $\begin{array}{c}\text { Cerami } \\
\mathrm{c} \\
\text { hollow } \\
\text { brick } \\
\text { with } \\
\text { insulati } \\
\text { on } \\
\end{array}$ & $530 / 3$ & $3.0 / 10$ & $603 / 2$ & $80 / 9$ & $2267 / 9$ & $125 / 10$ & $0 / 10$ & Warm & $\begin{array}{c}\text { Resista } \\
\text { nt }\end{array}$ & $\begin{array}{l}\text { Exp } \\
\text { ensi } \\
\text { ve }\end{array}$ \\
\hline 2 & $\begin{array}{c}\text { Cerami } \\
\mathrm{c} \\
\text { porous } \\
\text { blocks } \\
\end{array}$ & $470 / 4$ & $3.3 / 10$ & $467 / 4$ & $82.3 / 9$ & $2618 / 8$ & $100 / 8$ & $0 / 10$ & Warm & $\begin{array}{c}\text { Resista } \\
\mathrm{nt}\end{array}$ & \begin{tabular}{|l} 
Exp \\
ensi \\
ve
\end{tabular} \\
\hline 3 & \begin{tabular}{|c|} 
limesto \\
ne-shell \\
rock \\
with \\
insulati \\
on \\
\end{tabular} & $530 / 3$ & $3.1 / 9$ & $642 / 1$ & $80 / 9$ & $2587 / 8$ & $100 / 8$ & $5 / 6$ & Warm & $\begin{array}{l}\text { Not } \\
\text { resistent }\end{array}$ & \begin{tabular}{|c|} 
Exp \\
ensi \\
ve
\end{tabular} \\
\hline 4 & $\begin{array}{c}\text { Aerated } \\
\text { concret } \\
\mathrm{e}\end{array}$ & $420 / 5$ & 2.9/9 & $330 / 6$ & $84.6 / 9$ & $1840 / 9$ & $100 / 8$ & $2 / 8$ & Warm & $\begin{array}{c}\text { Resista } \\
\mathrm{nt}\end{array}$ & $\begin{array}{l}\text { Ave } \\
\text { rage }\end{array}$ \\
\hline 5 & $\begin{array}{c}\text { Rounde } \\
\mathrm{d} \text { logs } \\
\text { with } \\
\text { insulati } \\
\text { on } \\
\end{array}$ & $300 / 8$ & $3.1 / 9$ & $200 / 8$ & $88.4 / 9$ & $5065 / 4$ & $50 / 4$ & 10/1 & Warm & $\begin{array}{c}\text { Perm. } \\
\text { processi } \\
\text { ng } \\
\text { needed }\end{array}$ & $\begin{array}{l}\text { Exp } \\
\text { ensi } \\
\text { ve }\end{array}$ \\
\hline 6 & \begin{tabular}{|c|} 
Glued \\
laminat \\
ed \\
timber \\
\end{tabular} & $250 / 9$ & $3.2 / 10$ & 130/9 & $90.2 / 10$ & $7066 / 1$ & $50 / 4$ & $1 / 9$ & Warm & \begin{tabular}{c|} 
Perm. \\
processi \\
ng \\
needed \\
\end{tabular} & \begin{tabular}{|c|} 
Exp \\
ensi \\
ve
\end{tabular} \\
\hline 7 & \begin{tabular}{|c|} 
Movabl \\
$\mathrm{e}$ \\
modula \\
$\mathrm{r}$ \\
formwo \\
rk of
\end{tabular} & $400 / 6$ & $2.8 / 8$ & $420 / 4$ & $84.6 / 9$ & $\begin{array}{c}1630 / 1 \\
0\end{array}$ & $100 / 8$ & $1 / 9$ & Any & $\begin{array}{c}\text { Resista } \\
\text { nt }\end{array}$ & Low \\
\hline
\end{tabular}




\begin{tabular}{|c|c|c|c|c|c|c|c|c|c|c|c|}
\hline & $\begin{array}{l}\text { "TISE" } \\
\text { type }\end{array}$ & & & & & & & & & & \\
\hline 8 & $\begin{array}{c}\text { SIP- } \\
\text { panels }\end{array}$ & $\begin{array}{c}174 / 1 \\
0\end{array}$ & $3.1 / 9$ & $38 / 10$ & $93.1 / 10$ & $\begin{array}{c}1546 / 1 \\
0\end{array}$ & $30 / 2$ & $1 / 9$ & Any & $\begin{array}{c}\text { One- } \\
\text { time } \\
\text { processi } \\
\text { ng }\end{array}$ & Low \\
\hline 9 & $\begin{array}{c}\text { Perman } \\
\text { ent } \\
\text { formwo } \\
\text { rk } \\
\text { «Termo } \\
\text { dom, } \\
\text { Legodo } \\
\text { m, } \\
\text { Izodom } \\
\text { " }\end{array}$ & $340 / 7$ & $3.2 / 10$ & $386 / 5$ & $86.9 / 9$ & $1817 / 9$ & $100 / 8$ & $1 / 9$ & Any & $\begin{array}{c}\text { Resista } \\
n t\end{array}$ & Low \\
\hline 10 & $\begin{array}{c}\text { Fixed } \\
\text { formwo } \\
\text { rk } \\
\text { "Techn } \\
\text { oblok" }\end{array}$ & $350 / 7$ & $3.3 / 10$ & $465 / 4$ & $86.5 / 9$ & $2492 / 8$ & $80 / 6$ & $1 / 9$ & Any & $\begin{array}{c}\text { Single } \\
\text { processi } \\
\text { ng }\end{array}$ & Low \\
\hline 11 & $\begin{array}{c}\text { Fixed } \\
\text { formwo } \\
\text { rk } \\
« \text { Plastb } \\
\text { au» }\end{array}$ & $320 / 7$ & $3.2 / 10$ & $390 / 5$ & $87.6 / 9$ & $1876 / 9$ & $100 / 8$ & $1 / 9$ & Any & $\begin{array}{c}\text { Resista } \\
n t\end{array}$ & Low \\
\hline 12 & $\begin{array}{c}\text { Fixed } \\
\text { formwo } \\
\text { rk } \\
\text { "SOTA } \\
\text { 3-D } \\
\text { armed } \\
\text { panels» }\end{array}$ & $250 / 9$ & $3.2 / 10$ & $300 / 6$ & $90.2 / 10$ & $2369 / 9$ & $100 / 8$ & $1 / 9$ & Any & $\begin{array}{c}\text { Resista } \\
\text { nt }\end{array}$ & Low \\
\hline 13 & $\begin{array}{c}\text { Polysty } \\
\text { rene } \\
\text { concret } \\
\mathrm{e} \\
\text { blocks }\end{array}$ & $500 / 9$ & $3.1 / 9$ & $400 / 5$ & $81 / 9$ & $\begin{array}{c}1615 / 1 \\
0\end{array}$ & $100 / 8$ & $2 / 8$ & Any & $\begin{array}{c}\text { Resista } \\
\text { nt }\end{array}$ & Low \\
\hline 14 & $\begin{array}{c}\text { Cement } \\
\text { particle } \\
\text { boards }\end{array}$ & $640 / 1$ & $3.0 / 9$ & $560 / 2$ & $76 / 8$ & $3085 / 7$ & $100 / 8$ & $2 / 8$ & Any & $\begin{array}{c}\text { Resista } \\
n t\end{array}$ & Low \\
\hline 15 & $\begin{array}{c}\text { Patent } \\
\text { UA No. } \\
115636 \\
\text { "Multil } \\
\text { ayer } \\
\text { wall } \\
\text { panel" }\end{array}$ & $290 / 8$ & $3.1 / 9$ & $385 / 5$ & $88.7 / 10$ & $\begin{array}{c}1436 / 1 \\
0\end{array}$ & $100 / 8$ & $1 / 9$ & Any & $\begin{array}{c}\text { Resista } \\
\text { nt }\end{array}$ & Low \\
\hline 16 & $\begin{array}{c}\text { Patent } \\
\text { UA } \\
\text { No. } 115 \\
637 \\
\text { "Multil } \\
\text { ayer } \\
\text { enclosi } \\
\text { ng wall }\end{array}$ & $340 / 7$ & $3.1 / 9$ & $120 / 9$ & $86.9 / 9$ & $1807 / 9$ & $100 / 8$ & $1 / 9$ & Any & $\begin{array}{c}\text { Resista } \\
\text { nt }\end{array}$ & Low \\
\hline
\end{tabular}




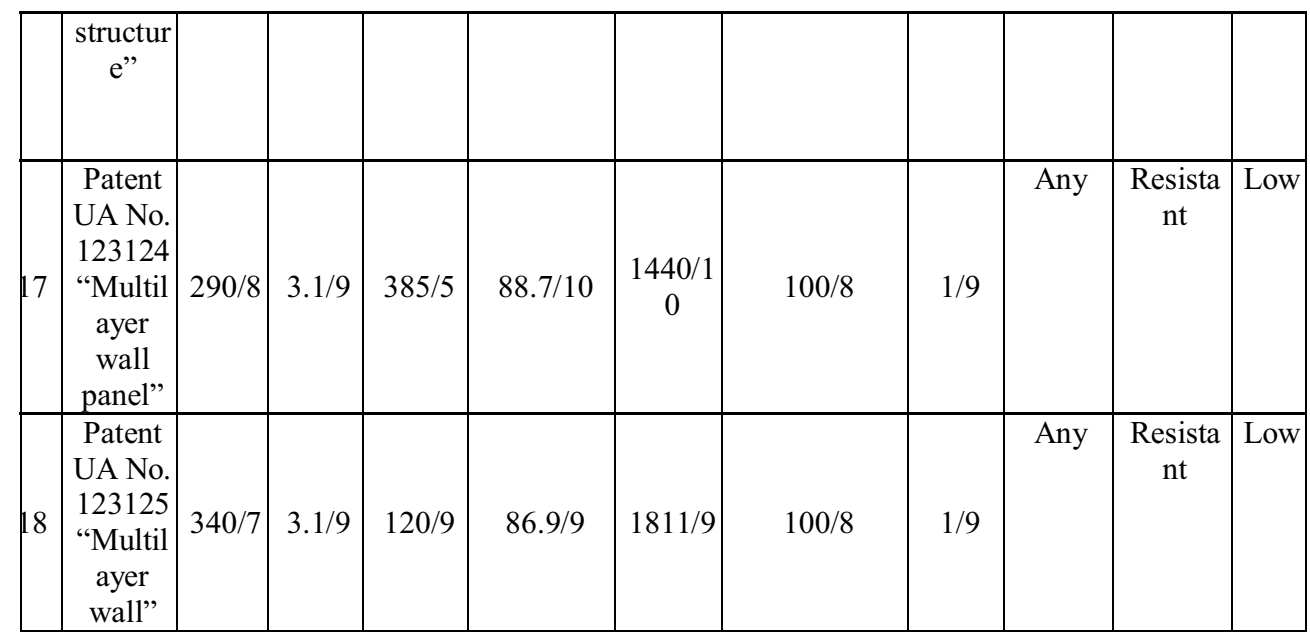

In the course of consideration and analysis of technologies, constructive solutions with the use of fixed formwork remained for subsequent comparison. A building made of permanent formwork is one of the most affordable types of individual housing construction, which is distinguished by reliability, economy and ease of construction of the entire structure. The building, erected using fixed formwork, has increased energy-saving characteristics, and in addition, the load on the foundation is significantly reduced, time, cost and labor intensity for construction are reduced [6].

These can be technologies for erecting buildings in fixed formwork such as "TISE", "Termodom, Legodom, Izodom", "Plastbau", "SOTA", 3-D reinforced panels, Multilayer wall panels under patents UA No. 115636, UA No. 115637 and UA No. 123124.

For the final decision on the choice of the optimal technology for the construction of buildings, we introduce the weighting coefficients of the criteria. They are used to establish the importance of each of the criteria. The importance of the criterion is determined as the sum of the products of the weighting coefficients of the criteria and the assessment of this criterion in points, as a result of which an integral assessment of the technology is obtained. In this case, the sum of the weight coefficients for all criteria should be equal to one. As a result, the equation of integral estimates makes the final choice of an effective solution.

According to the results of a comparative analysis, taking into account the "weight" factor, the most effective design solution for the patent UA No.123124 "Multilayer wall panel". It has the following indicators: the cost of building $1 \mathrm{~m} 2$ of enclosing structure UAH 1436. The thickness is $390 \mathrm{~mm}$ and the weight is $385 \mathrm{~kg}$. This provides $11 \%$ more usable indoor space than a brick wall $(603 \mathrm{~kg}$ and $530 \mathrm{~mm})$ with a building size of $10 \times 10$ $\mathrm{m}$ and a 1.5 times weight reduction. Resistance to heat transfer is provided at the level of $3.1 \mathrm{~m} 2 \cdot \mathrm{C} / \mathrm{W}$, which is higher than the normatively established $2.8 \mathrm{~m} 2 \cdot \mathrm{C} / \mathrm{W}$ for the II climatic zone. Also, one of the advantages is the ability to build at any time of the year, with the provision of resistance to moisture, mold and fungal infections of the wall (Fig. 1).

It provides not only the regulatory thermal characteristics, but also the requirements of fire safety standards, due to additional structural elements in the form of mineral wool inserts. They are fire cutoffs. Such elements are arranged at the floor level, around window, door and other openings. As a result, fire safety of the entire structure is ensured. 


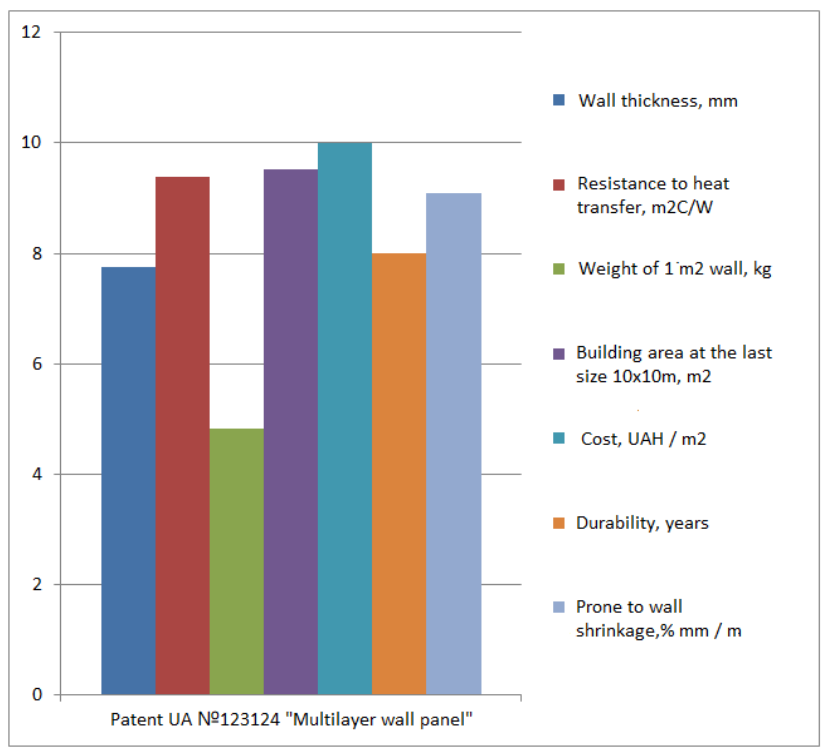

Fig. 1.The most effective design solution for the patent UA No. 123124 "Multilayer wall panel"

\section{Discussion}

The research results given in the work made it possible to determine the most effective solution for the arrangement of enclosing structures for "budgetary" low-rise buildings out of 18 considered solutions according to 10 efficiency criteria.

The development of this work can be demonstrated in the continuation of research on the developed new economical and effective solutions.

\section{Conclusion}

1. There is a problem of choosing structures with high thermal performance, low cost and labor costs for construction at present.

2. To solve the problem, the method of multi-criteria analysis can be used.

3. For the construction of low-rise buildings of the "budget" type of country cottages, you can use the technology developed under the patent UA No. 123124

\section{References}

1. Volumes of housing commissioned in Ukraine in 2017: State Statistics Service http://domik.ua/novosti/obemy-prinyatogo-v-ekspluataciyu-zhilya-v-ukraineza-2017-god-gosstat-n255275.html

2. Ye.Klymenko, I.Grynyova, Z. Kos, The Method of Calculating the Bearing Capacity of Compressed Stone Pillars, Proceedings of CEE 2019. Advances in Resource-saving Technologies and Materials in Civil and Environmental Engineering, Lviv, Ukraine, 161-167 (2019)

3. Yevhenii Klymenko, Zeljko Kos, Iryna Grynyova, Olena Maksiuta, Operation of Damager H-Shaped Columns, Springer Nature Switzerland AG 2021, Z. Blikcharskyy 
(Ed.), EcoComfort 2020, LNCE 100, 192-201 (2021) doi.org/10.10007/978-3-03057340-9_24

4. A.I.Meneylyuk, L.A.Cherepashchuk, New constructive solutions for energy-efficient kitchen gardening stin constructions, Collection of Science Materials of the XVI International Scientific and Practical Internet Conference "Achievements and Problems of Contemporary Science" June 22, 2018 Part 5, Vinnytsya, 80-88 (2018)

5. A.I.Meneylyuk, T.M.Dubelt, I.A. Meneylyuk,Innovatsii $v$ stroitelstve $i$ rekonstruktsii (K.:TOV NVP «InterservIs», 2018)

6. J.Fudge, S. Brown, Prefabricated modular concrete construction, Building engineer 86(6), 20-21 (2011)

7. N.Y. Gerges Samir, A.M. Balvedi,Numerical simulation and experimental tests of multilayer systems with porous materials, Appl. Acoust 58(4), 403 - 418(1999).

8. A.I. Meneylyuk, I.N.Babiy, N.V.Olejnik, L.A.Cherepaschuk,Investigation of the construction and installation works cost of at the construction of energy efficient buildings, Proceedings of VI International scientific conference, «Millennium Innovations in Science», March 30, 2018.- SI Universum, London, 4-9 (2018)

9. O.Meneylyuk, A.Nikiforov, I.Meneylyuk, Transport construction cost management by rational organizational and technological solutions, Eastern-European Journal of Enterprise Technologies $\mathbf{3 / 3}$ (105), 16-24 (2020) doi.org/10.15587/17294061.2020.205117 